\title{
FAKTOR YANG MEMENGARUHI FINANCIAL SATISFACTION PADA MASYARAKAT KABUPATEN PAMEKASAN
}

\author{
Dinda Arfiana Rusdini \\ Universitas Negeri Surabaya \\ Dindarusdini16080574124@mhs.unesa.ac.id
}

\begin{abstract}
The purpose of this research is to determine the influence of income, debt, and financial literacy on financial satisfaction through financial management behaviour as a mediating variable. This causality research using per capita income data from BPS shows that Pamekasan district has the lowest per capita income so that Pamekasan district as an object with a total sample of 193 respondents by offline questionnaire. Using SEM techniques and processed with AMOS tools, the conclusion is that only financial literacy influences financial management behaviour because of their high savings awareness. Income does not influence financial satisfaction because even their income is high enough, but they still have high debt. Debt does not affect financial satisfaction because having debt does not necessarily cause financial anxiety. Some respondents have debt and have financial satisfaction, but some do not. Financial literacy has no influence on financial satisfaction but influences financial management behaviour, and financial management behaviour has not been able to meditate because their saving behaviour is unable to increase their satisfaction.
\end{abstract}

Keywords: debt; financial literacy; financial management behavior; financial satisfaction; income.

\section{PENDAHULUAN}

Kesenjangan pendapatan masih sangat nampak di Indonesia. Kesenjangan ini ditinjau baik dari pergerakan roda perekonomian di wilayah tersebut, maupun pendapatan masyarakatnya. Hal tersebut bahkan dapat terjadi di wilayah yang letaknya berdekatan namun dengan perekonomian yang sangat berbanding terbalik. Di kepulauan Jawa, daerah dengan Produk Domestik Regional Bruto (PDRB) Per Kapita tertinggi yaitu Jawa Timur (Badan Pusat Statistik Jawa Timur, 2017). Sebagai provinsi dengan Produk Domestik Regional Bruto (PDRB) Per Kapita tertinggi, Jawa Timur pun masih terdapat perbedaan pendapatan yang mencolok terutama pendapatan di daerah perkotaan dan pendapatan di daerah Kabupaten (Badan Pusat Statistik Jawa Timur, 2017).

Lima daerah dengan penghasilan terendah dari total 40 Kabupaten dan Kota yang ada di Jawa Timur pada tahun 2017 yaitu Kabupaten Nganjuk, Kabupaten Ngawi, Kabupaten Ponorogo, Kabupaten Sampang, dan Kabupaten pamekasan (Badan Pusat Statistik Jawa Timur, 2017). Di Pulau Madura, Kabupaten dengan penghasilan per kapita tertinggi yaitu Kabupaten Sumenep. Ini menempatkan Kabupaten Sumenep di urutan ke 22 dalam daftar penghasilan perkapita Kabupaten dan Kota di Jawa Timur. Berbeda dengan Kabupaten Pamekasan yang berada di urutan ke 40 dari 40 Kabupaten dan Kota dalam daftar penghasilan per kapita tahun 2017. Penelitian ini menggunakan data pendapatan per kapita karena sejauh ini tidak ada indeks kepuasan keuangan yang digunakan untuk mengukur kepuasan keuangan, sehingga menggunakan data pendapatan per kapita (Aboagye \& Jung, 2018). Financial satisfaction menunjukkan persepsi individu tentang apakah sumber keuangan seseorang memadai atau tidak (Hasibuan \& Lubis, 2017).

Variabel pertama yang akan diteliti yaitu pendapatan. Penghasilan pribadi (pendapatan) merupakan pendapatan individu yang berasal dari segala sumber (Aboagye \& Jung, 2018). Menurut Cokuner (2016), Aboagye \& Jung (2018), dan Xin et al (2017), individu dengan penghasilan yang tinggi akan memiliki financial satisfaction yang tinggi pula. Variabel kedua yang akan diteliti yaitu hutang. Menurut Rusdini et al (2020), hutang merupakan tanggungan kewajiban yang belum terselesaikan kepada pihak lain. Hutang dapat berupa cicilan atau kredit. Garrett \& James (2013), Robb etal (2019) dan Plagnol (2011) mengemukakan bahwa kondisi di mana individu yang berhutang memiliki financial satisfaction rendah. 
Variabel ketiga yang akan diteliti yaitu financial literacy. Financial literacy adalah kecakapan keuangan seseorang yang nantinya akan berkontribusi memengaruhinya dalam bertindak (Otoritas Jasa Keuangan, 2014). Ini menandakan seberapa jauh individu melek keuangan sehingga ia mampu memberikan keputusan yang baik (Falahati et al, 2012). Kirbis et al (2016) dan Xiao et al (2013) mengemukakan bahwa semakin tinggi financial literacy individu maka akan mendorong financial satisfaction individu tersebut. Variabel mediasi yang digunakan yakni financial management behavior yang merupakan kehandalan individu dalam mengelola situsi keuangannya (Herdjiono dan Damanik, 2016). Sabri \& Falahati (2012) dan Falahati et al (2012) mengemukakan financial management behavior dapat menjadi variabel mediasi.

Tujuan dari penelitian ini yakni membuktikan apakah variabel pendapatan, hutang, dan financial literacy mampu memengaruhi financial satisfaction melalui financial management behavior sebagai variabel mediasi. Penelitian ini penting dilakukan karena menurut Aboagye \& Jung (2018) variabelnya merupakan penilaian yang cenderung subyektif atas bagaimana kondisi yang dirasakan saat itu. Selain karena hasil dari penelitian terdahulu yang masih ada gap, financial satisfaction juga erat kaitannya dengan pendapatan yang mana pendapatan berhubungan erat dengan kebutuhan hidup dan inflasi yang selalu meningkat, sehingga apabila penelitian ini dilakukan pada waktu dan sekelompok orang di wilayah yang berbeda akan memungkinkan hasil yang berbeda pula (Falahati et al, 2012).

\section{KAJIAN PUSTAKA DAN PENGEMBANGAN HIPOTESIS}

\section{Theory of Planned Behavior (TPB)}

Theory of Planned Behavior (TPB) merupakan teori yang melatarbelakangi individu dalam mempertimbangkan suatu informasi untuk melakukan suatu tindakan terutama dalam hal keuangannya. Teori tersebut mengemukakan bahwa individu akan berperilaku sesuai dengan apa yang mereka niatkan secara sadar (Ajzen, 1991). Niat individu umumnya didasari pada tiga hal yakni persepsi, norma, dan sikap yang dimilikinya. Ini mencerminkan individu yang menerapkan apa yang ia tahu dan apa yang ia yakini. Theory of Planned Behavior digunakan untuk mendasari terkait seberapa tinggi kepercayaan individu akan hasil yang mungkin akan diraih dengan melakukan suatu tindakan tertentu. Theory of Planned Behavior sangat relevan untuk menjelaskan Financial Literacy, dan Financial Management Behavior terhadap Financial Satisfaction (Falahati et al, 2012).

\section{Subjective Well-being Theory}

Subjective Well-Being Theory merupakan teori yang menggambarkan pandangan seseorang terkait kondisinya saat itu (Diener et al, 1999). Pandangan ini digambarkan melalui reaksi emosional yang dimiliki oleh sesorang atas suatu hal atau penilaian terkait kepuasan hidup yang mereka rasakan saat itu. Level Subjective Well-Being yang dirasakan oleh setiap individu dievaluasi sendiri melalui penilaian subyektif masing-masing individu. Subjective Well-Being Theory relevan untuk menjelaskan bagaimana seseorang memberikan penilaian pribadi atas suatu kondisi di hidupnya. Baik dari segi pendapatan, kebutuhan, dan segi lain dalam kehidupannya. Subjective Well-Being Theory dalam penelitian ini digunakan untuk menjelaskan bagaimana pengaruh variabel pendapatan dan hutang terhadap variabel financial satisfaction (Falahati et al, 2012).

\section{Hubungan antar Variabel}

Pendapatan merupakan tambahan nilai yang didapat oleh seseorang. Pendapatan dijelaskan melalui Subjective Well-Being Theory yang mendasari bahwa bahwa seseorang memiliki penilaian subyektif atas kondisi kehidupannya. Di samping itu, individu dengan pendapatan tinggi berada dalam keamanan finansial yang baik, sehingga terhindar dari kehawatiran keuangan (Aboagye \& Jung, 2018). Menurut Aboagye \& Jung (2018) dan Hasibuan \& Lubis (2017), pendapatan memiliki pengaruh positif terhadap Financial Satisfaction, di mana individu berpendapatan tinggi lebih condong memiliki kepuasan tinggi.

H1: Pendapatan berpengaruh terhadap financial satisfaction. 
Dinda Arfiana Rusdini. Faktor yang Memengaruhi Financial Satisfaction pada Masyarakat Kabupaten Pamekasan

Hutang merupakan tanggungan kewajiban yang belum terselesaikan kepada pihak lain. Tentunya ada informasi yang harus diketahui oleh seseorang sebelum berhutang, seperti ada risiko yang harus ditanggung oleh seseorang yang berhutang. Individu yang memiliki hutang cenderung memiliki kekhawatiran keuangan sehingga menurunkan kepuasan keuangan yang dimilikinya (Garrett \& James, 2013). Menurut Garrett \& James (2013), Robb et al (2019) dan Plagnol (2011), hutang memiliki pengaruh negatif terhadap financial satisfaction yang mana seseorang dengan hutang menggambarkan bahwa individu tersebut memiliki masalah keuangan sehingga memiliki kepuasan keuangan yang rendah.

$\mathrm{H} 2$ : Hutang berpengaruh terhadap financial satisfaction.

Financial literacy ialah suatu kecakapan keuangan yang dimiliki oleh seseorang (Rusdini et el, 2020). Financial literacy didasari oleh Theory of Planned Behavior (Ali et al, 2013). Menurut Xiao (2013), Sabri \& Gudmunson (2012), dan Ali et al (2013), financial literacy memiliki pengaruh positif terhadap financial satisfaction yang mana individu dengan literasi keuangan tinggi condong memiliki kepuasan keuangan tinggi.

H3: Financial literacy berpengaruh terhadap financial satisfaction.

Financial literacy ialah suatu kecakapan keuangan yang dimiliki oleh seseorang (Falahati et al, 2012). Financial literacy di dasari oleh Theory of Planned Behavior (Falahati et al, 2012). Menurut Sabri \& Falahati (2012) dan Falahati et al (2012), financial literacy menunjukkan adanya pengaruh signifikan positif terhadap financial management behavior di mana individu dengan literasi keuangan yang tergolong baik cenderung berpuas diri terhadap kondisi keuangannya.

\section{H4: Financial management behavior berpengaruh terhadap financial satisfaction.}

Financial management behavior merupakan perilaku tata kelola keuangan yang baik (Aboagye \& Jung, 2018). Variabel ini didasari oleh Theory of Planned Behavior (Aboagye \& Jung, 2018). Semakin baik individu dapat mengelola keuangannya, maka ia akan memiliki kepuasan keuangan yang semakin tinggi pula (Aboagye \& Jung, 2018). Menurut Aboagye \& Jung (2018) dan Coşkuner (2016), financial management behavior memiliki pengaruh signifikan positif terhadap financial satisfaction yang individu dengan tata kelola keuangan baik lebih condong berperilaku keuangan baik sehingga mendorong kepuasan keuangan.

H5: Financial literacy berpengaruh terhadap financial management behavior.

Kemampuan dalam mengalokasikan finansial dengan efektif merupakan penentu utama financial satisfaction. Pengaruh financial literacy terhadap financial satisfaction melalui financial management behavior dijelaskan melalui Theory of Planned Behavior yang diasumsikan individu dengan pemahaman financial literacy mampu membangun financial management behavior (Falahati et al, 2012). Menurut Sabri \& Falahati (2012) dan Falahati et al (2012), financial management behavior dapat menjadi variabel mediasi.

H6: Financial satisfaction berpengaruh terhadap financial satisfaction melalui financial management behavior.

\section{METODE PENELITIAN}

Penelitian ini merupakan jenis penelitian kausalitas dengan metode kuantitatif. Data bersumber dari kuesioner offline yang diberi kode untuk ditabulasi kemudian olah statistik dengan metode Structural Equation Model (SEM) menggunakan AMOS. Adapun tahapan pengolahan data yakni dilakukan uji validitas dan reliabilitas, uji normalitas, uji outlier, kemudian uji hipotesis untuk membuktikan adanya pengaruh antar variabel. Uji Sobel juga dilakukan untuk menguji apakah terdapat mediasi. Sampel diperoleh dengan cara mengalikan indikator yang berjumlah $35 \times 5=175$. Sampel yang berjumlah 
175 dikalikan 10\% sehingga menghasilkan 193 responden. Responden merupakan masyarakat Kabupaten Pamekasan yang memiliki pendapatan dan hutang. Sampel diambil dengan teknik random sampling.

\section{HASIL DAN PEMBAHASAN}

\section{Uji Validitas dan Reliabilitas}

Variabel financial literacy dan financial satisfaction memenuhi nilai minimum ave yakni $>0.50$. sedangkan untuk variabal financial management behavior nilainya setara dengan nilai minimum yakni 0.502. Hal ini dapat dikatakan bahwa variabel memiliki nilai convergent yang rendah. Construct reliability tergolong sangat baik karena memiliki nilai jauh dari angka minimum yaitu $>0.70$ (yang disyaratkan baik), sedangkan untuk nilai discriminant validity pada variabel financial literacy dan financial satisfaction sangat bagus karena berada di atas 0.70, sedangkan untuk variabel Financial Management Behavior nilainya ada pada nilai minimum yakni 0.702. Pada uji normalitas ini terdapat beberapa data yang berdistribusi secara tidak normal, yaitu X33, X32, dan X31 yang memiliki nilai di atas 2.58. Data yang berdistribusi secara tidak normal tersebut perlu dilakukan eliminasi dan melanjutkan pengujian dengan data yang lolos uji normalitas ke uji outlier. Pada uji outlier terdapat 4 responden dengan uji outlier di bawah 0.05 yakni pada responden 140, 9, 165, dan 172. sehingga dapat dikatakan bahwa responden tersebut tidak lulus uji outlier sehingga tersisa 189 dari 193 responden.

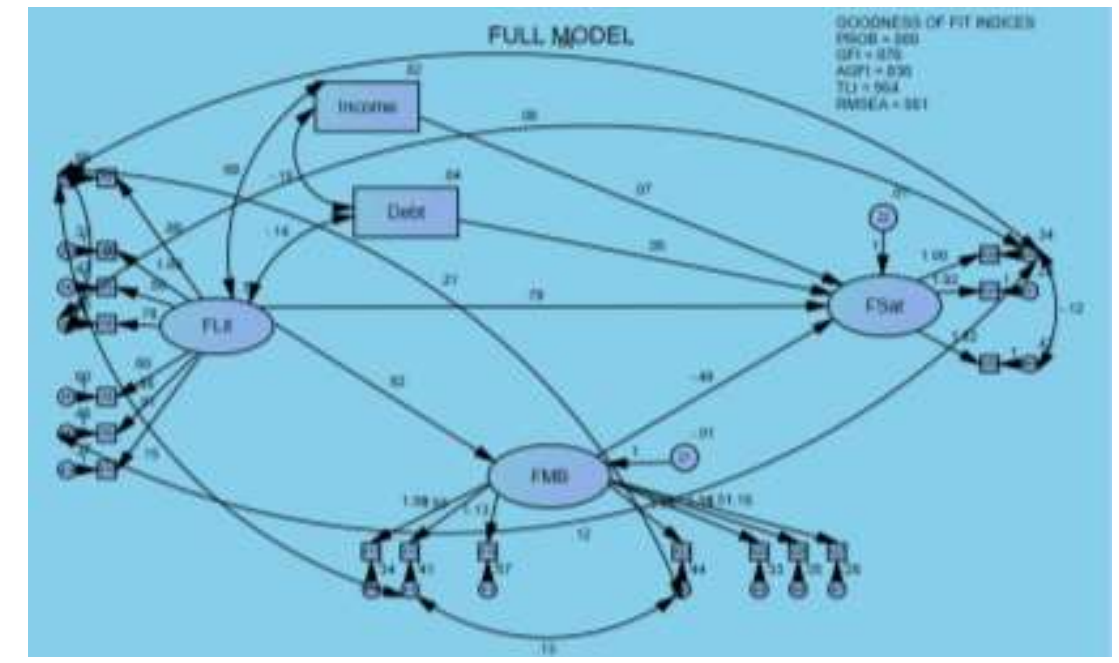

Sumber: Output AMOS

Gambar 1. MODEL AKHIR SEM

Berdasarkan Model Akhir SEM pada Gambar 1, Nilai GFI dan AGFI dikatakan marginal karena tidak mencapai namun mendekati nilai minimum yakni GFI 0.876 dan nilai AGFI 0.830 yang seharusnya lebih besar dari 0.90. Nilai TLI tergolong baik karena memiliki nilai di atas nilai minimum yakni $0.954 \geq 0.950$. Sedangkan untuk RMSEA tergolong baik karena memiliki nilai di antara $0.080 \leq X \geq$ 0.050 yakni sebesar 0.061 .

\section{Uji Hipotesis}

Uji Hipotesis dilakukan dengan melihat besarnya nilai probabilitas yang muncul sebesar 0.05 sekaligus besarnya nilai critical ratio sebesar 2.00. Tabel 1 menunjukkan bahwa hanya H1 yakni variabel financial literacy menunjukkan adanya pengaruh terhadap financial management behavior. Di samping itu variabel lain tidak menunjukkan adanya pengaruh dikarenakan nilai signifikasi melampaui 0.05 sehingga dikatakan tidak menunjukkan adanya pengaruh. Mediasi dibuktikan dengan menggunakan uji sobel test dan tidak ditemukan adanya mediasi, sehingga financial management behavior belum mampu memediasi variabel financial literacy terhadap financial satisfaction. 
Dinda Arfiana Rusdini. Faktor yang Memengaruhi Financial Satisfaction pada Masyarakat Kabupaten Pamekasan

Tabel 1.

HASIL UJI HIPOTESIS

\begin{tabular}{llllllll}
\hline & Variabel & Estimate & S.E. & C.R. & P & Test Statistic & P-Value \\
\hline H1 & Inc $\rightarrow$ FS & 0.075 & 0.048 & 1.544 & 0.123 & & \\
H2 & Debt $\rightarrow$ FS & 0.055 & 0.155 & 0.352 & 0.725 & & \\
H3 & FLit $\rightarrow$ FS & 0.792 & 0.561 & 1.411 & 0.158 & & \\
H4 & FLit $\rightarrow$ FMB & 0.623 & 0.060 & 10.375 & 0.000 & & \\
H5 & FMB $\rightarrow$ FS & -0.493 & 0.925 & -0.533 & 0.594 & & \\
H6 & FLit $\rightarrow$ FMB $\rightarrow$ FS & & & & & -0.474 & 0.635 \\
\hline
\end{tabular}

Sumber: Output AMOS (data di olah)

\section{Pengaruh Pendapatan terhadap Financial Satisfaction}

Berdasarkan pengujian hipotesis pada tabel 2, pendapatan tidak menunjukkan adanya pengaruh terhadap financial satisfaction. Temuan berikut sejalan dengan Rusdini et al (2020), Plagnol (2011), dan Hansen et al (2008) yang mengemukakan pendapatan tidak memiliki pengaruh pada financial satisfaction. Implikasi pada penelitian ini tidak sejalan dengan teori Subjective Well-being Theory yang melandasi variabel pendapatan. Subjective Well-being Theory menggambarkan kondisi individu berpendapatan kategori tinggi cenderung merasa cenderung mempunyai kepuasaan lebih akan kondisi keuangannya. Berdasarkan data kuesioner responden paling banyak memiliki pendapatan di atas UMR yang berlaku di Kabupaten Pamekasan. Dengan teori Subjectie Well-being Theory maka seharusnya responden memiliki kepuasan keuangan yang tinggi pula. Di lain sisi berdasarkan hasil wawancara responden didapati memiliki tanggungan yang cukup tinggi pula seperti kredit kendaraan. Implikasi praktik pada penelitian ini yakni walaupun memiliki pendapatan yang tinggi, juga terdapat tanggungan keuangan yang tinggi. Masyarakat Kabupaten Pamekasan sebaiknya lebih menata kelola keuangannya dengan lebih baik lagi sebagai contoh mengalokasikan keuangannya yang tergolong tinggi ke beberapa produk di bank seperti tabungan atau investasi.

\section{Pengaruh Hutang terhadap Financial Satisfaction}

Hutang tidak terbukti memiliki pengaruh terhadap financial satisfaction. Hal ini sesuai dengan Rusdini et al (2020), Aboagye \& Jung (2018), dan Seay \& Asebedo (2015) yang mengatakan bahwa hutang tidak berpengaruh signikan terhadap financial satisfaction. Implikasi pada penelitian ini yakni hasil yang didapat tidak sesuai dengan Theory of Planned Behavior yang melatarbelakangi individu dalam pengambilan keputusan dengan pertimbangan yang matang dan pikiran rasional. Implikasi praktik pada penelitian ini yakni keputusan hutang tidak selalu di latarbelakangi oleh kekhawatiran keuangan. Beberapa responden memilih untuk berhutang karena terpaksa dikarenakan kondisi keuangan yang mendesak untuk memenuhi kebutuhan sehingga menimbulkan kehawatiran keuangan. Di samping itu beberapa di antaranya berhutang karena tergiur dengan imbalan yang diberikan yang mana justru menimbulkan kepuasan keuangan karena merasa telah berhemat atau saving, contohnya cashback dan diskon bagi pemegang kartu kredit tertentu yang sukses menarik minat responden. Kondisi tersebut membuat beberapa responden yang memiliki hutang tetap memiliki kepuasan keuangan dengan sumber pendapatan yang cukup besar dan bukan karena terpaksa melainkan karena keinginan pribadi dan sukarela. Masyarakat Kabupaten Pamekasan sebaiknya lebih selektif dan mempertimbangkan lebih jauh tentang dampak yang harus ditanggung ketika memiliki hutang.

\section{Pengaruh Financial Literacy terhadap Financial Satisfaction}

Financial literacy tidak memiliki pengaruh terhadap financial satisfaction. Temuan ini sejalan dengan Kirbis et al (2016), Yap et al (2016), dan Rusdini et al (2020) yang menyatakan bahwa financial literacy tidak memiliki pengaruh terhadap financial satisfaction. Implikasi pada penelitian ini yakni hasil yang didapat tidak sejalan dengan Theory of Planned Behavior yang melatarbakangi individu dalam pengambilan keputusan dengan pertimbangan dan pikiran rasional. Semakin baik ia paham, semakin baik pula ia bertindak. Implikasi praktik pada penelitian ini yakni tingkat literasi keuangan responden berbeda beda, sehingga tindakan yang diambil akan berbeda beda. Melalui hasil ini, perlu adanya tindakan dari pemerintah untuk membuat program dan bimbingan dalam memajukan literasi keuangan masyarakat Kabupaten Pamekasan. Selain itu, masyarakat Kabupaten Pamekasan perlu 
untuk memperdalam literasi keuangan. Informasi tersebut pada masa modern ini sangat mudah diakses melalui jaringan internet.

\section{Pengaruh Financial Literacy terhadap Financial Management Behavior}

Financial literacy memiliki pengaruh terhadap financial management behavior. Ini menandakan bahwa financial literacy memiliki pengaruh terhadap financial management behavior. Temuan ini sejalan dengan Falahati et al (2012), Sabri \& Falahati (2012), dan Arofah et al (2018), di mana financial literacy memiliki pengaruh terhadap financial management behavior. Implikasi dari penelitian ini mendukung Theory of Planned Behavior yang mendasari individu dalam pengambilan keputusan dengan pertimbangan dan pikiran rasional. Implikasi praktik pada penelitian ini yakni individu yang memiliki literasi keuangan baik memungkinkannya mengimplementasikan dengan tindakan baik. Ini merupakan hal yang cukup baik sehingga pemerintah dapat bekerja sama dengan bank untuk terus menggencarkan perilaku menabung ini mengingat bahwa kesadaran menabung masyarakat cukup tinggi. Namun bukan berarti kesadaran ini tidak akan pernah turun, karena risk tolerance masyarakat cukup rendah sehingga sangat memungkinkan dalam menurukan kesadaran masyarakat akan menabung yang tadinya tinggi. Selain perlunya program dukungan dari pemerintah untuk meningkatkan literasi keuangan yang dimiliki, Masyarakat Kabupaten Pamekasan sebaiknya lebih memperdalam pengetahuan tentang produk keuangan di bank dan mengkaji dengan baik risiko yang mungkin terjadi apabila mereka memilih untuk menggunakan produk keuangan tersebut. Beberapa produk bank seperti menabung memiliki risiko yang sangat kecil dibandingkan dengan investasi.

\section{Pengaruh Financial Management Behavior terhadap Financial Satisfaction}

Financial management behavior tidak memiliki pengaruh terhadap financial satisfaction. Hal ini sejalan dengan hasil penelitian dari Kirbis et al (2016) dan Xiao et al (2013), financial management behavior tidak memiliki pengaruh terhadap financial satisfaction. Implikasi dari hasil temuan tersebut tidak sejalan dengan Theory of Planned Behavior yang melatarbelakangi seseorang dalam pengambilan keputusan dengan pertimbangan dan pikiran rasional. Implikasi praktik pada penelitian yakni responden terkadang juga memiliki kondisi di mana mereka tidak dapat berpikir rasional karena permasalahan yang mereka hadapi sehingga cenderung goyah saat mengambil keputusan. Kondisi psikologis dan informasi yang di dapat terkait suatu produk keuangan sangat memengaruhi dalam proses pengambilan keputusan. Pemerintah sebaiknya bekerjasama dengan bank dalam menyalurkan informasi tentang produk keuangan sehingga di harapkan mendorong ketertarikan masyarakat contohnya dalam menabung.

\section{Pengaruh Financial Literacy terhadap Financial Satisfaction melalui Financial Management Behavior}

Financial management behavior belum mampu memediasi financial literacy terhadap financial satisfaction. Hasil ini sejalan dengan Yap et al (2016), financial management behavior belum mampu memediasi financial literacy terhadap financial satisfaction. Hal ini dikarenakan semakin responden memiliki pengetahuan tentang suatu produk keuangan, kekhawatiran mengenai risiko yang mungkin di timbulkan akan semakin besar. Berdasarkan hasil dari wawancara mereka khawatir akan risiko yang harus ditanggung seperti kehilangan uang untuk berinvestasi. Implikasi tersebut bertolak belakang dengan Theory of Planned Behavior yang menggambarkan kondisi individu dengan pola pikir baik yang diimplementasikan melalui tindakan sehingga meningkatkan kepuasan keuangan yang mereka miliki. Implikasi praktik pada penelitian ini yakni tingkat melek keuangan dan perilaku menabung yang dilakukan oleh masyakarat Kabupaten Pamekasan belum mampu meningkatkan Financial Satisfaction yang dimiliki oleh responden. Perlu adanya langkah dalam menerapakan perilaku keuangan yang baik karena contoh penerapannya tidak hanya melalui menabung. Pemerintah baiknya melakukan kerjasama dengan instansi terkait dalam upaya memajukan perilaku keuangan yang baik. Pemerintah dapat menggandeng mahasiswa setempat dalam mengedukasi Masyarakat dan menarik minat masyarakat dalam berperilaku keuangan yang baik. 
Dinda Arfiana Rusdini. Faktor yang Memengaruhi Financial Satisfaction pada Masyarakat Kabupaten Pamekasan

\section{KESIMPULAN}

Pendapatan, hutang, dan financial literacy tidak menunjukkan adanya pengaruh terhadap financial satisfaction. Temuan tersebut disebabkan oleh pendapatan yang cukup baik tidak mampu meningkatkan financial satisfaction yang mereka miliki karena walaupun pendapatan yang di dapat tergolong tinggi namun mereka memiliki hutang yang harus mereka bayarkan. Hutang yang di sebabkan oleh financial anxiety seharusnya menurunkan financial satisfaction responden, namun dalam penelitian ini beberapa hutang dilatarbelakangi oleh perilaku saving karena maraknya program cashback dan discount yang justru meningkatkan financial satisfaction responden. Financial literacy memiliki pengaruh terhadap financial management behavior di sebabkan karena kesadaran yang cukup tinggi tentang menabung dan telah mempraktikkannya dalam jangka waktu yang cukup lama. Financial management behavior belum mampu memediasi financial literacy terhadap financial satisfaction dikarenakan hanya perilaku menabung yang dilakukan oleh responden dengan tidak memperhatikan aspek lain dalam perilaku keuangan yang baik sehingga kurang mampu dalam meningkatkan financial satisfaction yang dimiliki.

Keterbatasan dari penelitian ini yakni sampel yang cukup sedikit dan jangkauan wilayah yang cukup sempit yakni hanya bersumber di satu wilayah dengan menggunakan random sampling di karenakan tidak diizinkan untuk mengambil sampel dari seluruh kecamatan di tengah pandemi. Pemerintah kabupaten pamekasan sebaiknya meningkatkan program dalam peningkatan literasi keuangan. Masyarakat kabupaten pamekasan sebaiknya mengakses materi tentang informasi keuangan yang dapat diakses di internet, buku tentang bagaimana cara mengelola keuangan dengan baik, dan beberapa media lain yang berisi informasi terkait keuangan. Ini akan menambah pengetahuan sebelum nantinya mencoba menggunakan produk keuangan yang diminati. Penelitian selanjutnya diharapkan dapat menambahkan variabel financial knowledge dan financial attitude, serta memperluas jangkauan wilayah dan memperbanyak sampel penelitian.

\section{DAFTAR PUSTAKA}

Aboagye, J., \& Jung, J. Y. (2018). Debt holding, financial behavior, and financial satisfaction. Journal of Financial Counseling and Planning, 29(2), 208-218. https://doi.org/10.1891/10523073.29.2.208

Ali, A., Rahman, M. S. A., \& Bakar, A. (2013). Financial Literacy and Satisfaction in Malaysia: A Pilot Study. International Journal of Trade, Economics and Finance, December 2014, 319324. https://doi.org/10.7763/ijtef.2013.v4.309

Arifin, A. Z. (2018). Influence factors toward financial satisfaction with financial behavior as intervening variable on Jakarta area workforce. European Research Studies Journal, 21(1), 90103.

Arofah, A. A., Purwaningsih, Y., \& Indriayu, M. (2018). Financial Literacy, Materialism and Financial Behavior. International Journal of Multicultural and Multireligious Understanding, 5(4), 370. https://doi.org/10.18415/ijmmu.v5i4.171

Asandimitra, Nadia; dan Kautsar, Achmad. (2019). The Influence Of Financial Information, Financial Self Efficacy, And Emotional Intelligence To Financial Management Behavior Of Female Lecturer, Humanities \& Social Sciences Reviews, 7(6), 1112-1124.

Chwah, C.X., Goh, W.C., Lim, J.H., Tai, W.L. and Tan, W. W. (2018). Determinants Of Financial Satisfaction By Yap Yee Lin A research project submitted in partial fulfillment of the requirement for the degree of Bachelor Of Finance ( Hons ) Faculty Of Business And Finance Department Of Finance. Malaysian Academic Library Institutional Repository, April.

Clark, A. E., Senik, C., \& Yamada, K. (2013). The Joneses in Japan: pendapatan Comparisons and 
Financial Satisfaction. SSRN Electronic Journal, 866. https://doi.org/10.2139/ssrn.2233223

Coşkuner, S. (2016). Understanding Factors Affecting Financial Satisfaction: The Influence of Financial Behavior, Financial Knowledge and Demographics. Imperial Journal of Interdisciplinary Research, 2(5), 2454-1362.

Davis, K., \& Runyan, R. C. (2016). Personality traits and financial satisfaction: Investigation of a hierarchical approach. Journal of Financial Counseling and Planning, 27(1), 47-60. https://doi.org/10.1891/1052-3073.27.1.47

Diener, E., Suh, E. M., Lucas, R. E., \& Smith, H. L. (1999). Subjective well-being: Three decades of progress. Psychological Bulletin, 125(2), 276-302. https://doi.org/10.1037/00332909.125.2.276

Falahati, L., Sabri, M. F., \& Paim, L. H. J. (2012). Assessment a model of financial satisfaction predictors: Examining the mediate effect of financial behaviour and financial strain. World Applied Sciences Journal, 20(2), 190-197. https://doi.org/10.5829/idosi.wasj.2012.20.02.1832

Fazli Sabri, M., Cook, C. C., \& Gudmunson, C. G. (2012). Financial well-being of Malaysian college students. Asian Education and Development Studies, 1(2), 153-170. https://doi.org/10.1108/20463161211240124

Ferrer-i-Carbonell, A., \& Gërxhani, K. (2011). Financial Satisfaction and (in)formal Sector in a Transition Country. Social Indicators Research, 102(2), 315-331. https://doi.org/10.1007/s11205-010-9684-6

Fishbein, M., \& Ajzen, I. (2005). The Influence of Attitudes on Behavior. The Handbook of Attitudes, January 2005, 173-222. https://doi.org/10.1007/BF02294218

Garrett, S., \& James III, R. N. (2013). Financial Ratios and Perceived Household Financial Satisfaction. Journal of Financial Therapy, 4(1). https://doi.org/10.4148/jft.v4i1.1839

Grable, J. E., Cupples, S., Fernatt, F., \& Anderson, N. R. (2013). Evaluating the Link Between Perceived pendapatan Adequacy and Financial Satisfaction: A Resource Deficit Hypothesis Approach. Social Indicators Research, 114(3), 1109-1124. https://doi.org/10.1007/s11205-012$0192-8$

Hakim, F. A., Sunarti, E., \& Herawati, T. (2014). Manajemen Keuangan dan Kepuasan Keuangan Istri pada Keluarga dengan Suami Istri Bekerja. Jurnal Ilmu Keluarga Dan Konsumen, 7(3), 174-182. https://doi.org/10.24156/jikk.2014.7.3.174

Halim, Y. K. E., \& Astuti, D. (2015). Financial Stressors, Financial Behavior, Risk Tolerance, Financial Solvency, Financial Knowledge, dan Kepuasan Finansial. Jurnal Finesta, 3(1), 1923. https://doi.org/10.1109/EDOC.2009.26

Hansen, T., Slagsvold, B., \& Moum, T. (2008). Financial satisfaction in old age: A satisfaction paradox or a result of accumulated wealth? Social Indicators Research, 89(2), 323-347. https://doi.org/10.1007/s11205-007-9234-z

Jatimbps.go.id. 2017. Produk Domestik Regional Bruto. (https://jatim.bps.go.id/subject/52/produkdomestik-regional-bruto.html. Diakses pada 11 Februari 2020).

Jian, J., Chen, C., \& Chen, F. (2014). Consumer financial capability and financial satisfaction. Social Indicators Research, 118(1), 415-432. https://doi.org/10.1007/s11205-013-0414-8 
Dinda Arfiana Rusdini. Faktor yang Memengaruhi Financial Satisfaction pada Masyarakat Kabupaten Pamekasan

Kane, S. N., Mishra, A., \& Dutta, A. K. (2016). Preface: International Conference on Recent Trends in Physics (ICRTP 2016). Journal of Physics: Conference Series, 755(1). https://doi.org/10.1088/1742-6596/755/1/011001

Kautsar, A., \& Asandimitra, N. (2019). Financial Knowledge as Youth Preneur Success Factor. Journal of Social Development Science. Vol. 10, No.2, 2019, pp.26-32

Kirbis, I. Š., Vehovec, M., \& Galic, Z. (2016). Relationship Between Financial Satisfaction and Financial Literacy : Exploring. Drus Istraz Zagreb God, 26(2), 165-185.

Parmitasari, R. D. A., Hamsah, D., Alam, S., \& Laba, A. R. (2018). Analysis of Ethics and Investor Behavior and Its Impact on Financial Satisfaction of Capital Market Investors. Scientific Research Journal (SCIRJ), VI(I), 51-69. www.scirj.org

Plagnol, A. C. (2011). Financial satisfaction over the life course: The influence of assets and liabilities. Journal of Economic Psychology, 32(1), 45-64. https://doi.org/10.1016/j.joep.2010.10.006

Purwidianti, W., \& Tubastuvi, N. (2019). The Effect of Financial Literacy and Financial Experience on SME Financial Behavior in Indonesia. Jurnal Dinamika Manajemen, 10(1), 40-45. https://doi.org/10.15294/jdm.v10i1.16937

Rinofah, R., \& Sari, P. P. (2019). Peran Mediasi Capaian Finansial: Praktek Manajemen Keuangan Dan Kepuasan Finansial Pedagang Batik Dan Souvenir Di Pasar Beringharjo Yogyakarta. Jurnal Kewirausahaan Dan Bisnis, 24(13), 48. https://doi.org/10.20961/jkb.v24i13.29084

Robb, C. A., Chatterjee, S., Porto, N., \& Cude, B. J. (2019). The Influence of Student Loan Debt on Financial Satisfaction. Journal of Family and Economic Issues, 40(1), 51-73. https://doi.org/10.1007/s10834-018-9599-y

Rusdini, D. A., Indah, T., Mulyaningsih, S., Ghaisani, I., \& Kautsar, A. (2020). Impact of Financial Knowledge, Socio-Demographics, and Debt on Financial Satisfaction of Kediri People. 05(01), 6-9.

Sabri, M., \& Falahati, L. (2012). Estimating a Model of Subjective Financial Well-Being among College Students. International Journal of Humanities and Social Science, 2(18), 191-199.

Seay, M., Asebedo, S., Thompson, C., Stueve, C., \& Russi, R. (2015). Mortgage holding and financial satisfaction in retirement. Journal of Financial Counseling and Planning, 26(2), 200-216. https://doi.org/10.1891/1052-3073.26.2.200

Yap, R. J. C., Komalasari, F., \& Hadiansah, I. (2018). The Effect of Financial Literacy and Attitude on Financial Management Behavior and Satisfaction. Bisnis \& Birokrasi Journal, 23(3). https://doi.org/10.20476/jbb.v23i3.9175

Yen, H. P., Jo-Lyn, N., \& Keat, S. M. (2013). Financial Satisfaction Among The Urban Elderly In Selangor, Malaysia By Ho Pooi Yen Ng Jo-Lyn Siew Mun Keat A research project submitted in partial fulfillment of the requirement for the degree of Bachelor Of Economics (Hons) Global Economics Faculty O. Malaysian Academic Library Institutional Repository, April. 